$$
\begin{gathered}
\text { 대한민국 일개 농촌지역의 결핵감염율 } \\
\text { 이화여자대학교 의과대학 예방의학교실 } \\
\text { 구 연 철·이 기 용·강 지 용 }
\end{gathered}
$$

-Abstract-

\author{
The Result of Tuberculin Test in one Rural Community \\ Youn Choul, Koo, Ki Young, Lee and Ji Yong, Kang, M.D. \\ Department of Preventive Medicine Medical College of Ewha Women's University
}

\title{
Introduction
}

Yang-ju Gun Su-Dong Myun is rural health demonstration area of medical college, Ewha Womens University which has been established since 1963. During the last 3 years, basic comphrehensive health control pattern was established already by family record system by natural villages and ries.

The purpose of this survey study is not only for the actual basic TB control program of the area but also for the establishment of an economic TB case-finding screening method.

\section{Outline of the Survey}

TB test was carried on to the entire children below 15 years of age in both sexes in the area. survey team was composed of 4 staffs in medical collage 46 medical students.

Survey period was from Jan. 11, 1969 to 12 , 1969, all children were tested with $5 \mathrm{~T}$. U. old tuberculin by mantoux test and reading of the Reaction were carried out.

This is a report on the result of tuberculin reaction.

The range of induration size, and the correlation between tuberculin positive rate and B.C.G. scar.

\section{Result of Survey}

1) Among the 1338 population 1140 were completed tuberculin test; Average response rate was $85.2 \%$.

2) The rate of positive tuberculin reaction (average in both sexes) were $15.8 \%$, male were $16.5 \%$ female were $14.9 \%$.

The rate was higher in male than female.

The rate also increased in proportion to the age in both sexes.

The rate was $0 \%$ for $0-1$ years of age and $33.9 \%$ for $14-15$ years of age.

3 ) In tuberculin reactions according to induration size, induration size $11-15 \mathrm{~mm}$ was highest value; $6.8 \%$ for male $6.3 \%$ for female

in age groups also $11-15 \mathrm{~mm}$ was highest value; $1.9 \%$ for $0-5$ years of age $9.8 \%$ for $6-15$ years of age

4) The percentage of examinees with old B.C.G. scar was $19.8 \%$ female was $18.0 \%$, male is $19.9 \%$ The rate was higher in male than female.

5) The rate of positive tuberculin reactions among examinees without old B.C.G. scar was $16.1 \%$, and $14.4 \%$ in examinees with old B.C.G. scar

0-5 years of age; The rate was $5.5 \%$ in the non vaccinated and $8.3 \%$ in the vaccinated 
결핵 및 호홉기질환 Vol. 16, No. 4, October, 1969

6-15 years of age; The rate was $26.3 \%$ in the non vaccinated and $14.8 \%$ in the vaccinated

We observed lower positive rate in higher age even the B.C.G. was vaccinated.

서 론

본 조사지역은 이미 1967년 이화여자대학교 의 과대학 의 건강관리 시범지역으로 선정되어 인구조사 및 출생 사 망, 환경위생등이 조사되었으며 가정기록보가 확립된 지 역이다 여기 발표하는 것은 건강관리 사업중의 하나인 종 합결핵관리를 착수하는데 있어서 기초작업중의 하나로 신생아 및 15 세미만의 전아동층의 완전 면역실시를 위하 여 실시된 Tuberculin검사 결과를 분석 보고하는것이다. 또한 이 결과는 앞으로 실시될 X-Ray 집단검진에 의한 환자발견 결과와 종합 검토하여 결핵감염 人ㅁㅇㅢ tuberculin 양성 단위 가정분포를 정 확히 파악함으로써 아동충의 tuberculin test 결과로서도 결핵환자 발견의 경제적 sereening 방법이 되지않을까 하는데 목적을 두었다.

\section{연구대상 및 방법}

\section{1) 연구지역 및 기간}

경기도 양주군 수동면 북부 7 개리의 만 15 세미만 남 녀아동을 대상으로 의 과대학생 7 명 의 과대학교수 2 명 간 호원 2 명이 동원되었으며 기간은 1969년 1월 12 일 부터 18 일까지 7일간에 결쳐 tuberculin주사 판독 과거 B.C.G. 접종에 대해서 조사 연구하였다.

\section{2) 방법 및 실험 재료}

실시방법은 1967년 이미 작성한 가정기록보에 기재된 15세미만 아동의 인구를 기본으로 하였으며 tuberculin 검사 대상자 각 개인에 해당해서 필요한 질의종목을 기 록한 보조카一드를 작성하였다. 편의상 각자연부락별로 검사실시 장소를 정하고 이장을 통해서 전원 응진케 하였 으며 필요시에는 가정 방문을 통해서 가능한 검사를 실 시케 하였다. 실험재료는 국립방역 연구소제 old tuberculin 5T.U. 1:2000을 사용하고 전 시험기간 동안 동일 한 tuberculin 시약을 사용하였다. 1cc 주사기에 25 26 cage 의 바늘을 사용하였다. 검사방법은 가장 보편화된 mantoux test 로서 피내주사 방법을 사용하였고 주사부 위는 좌측전박굴측먼을 2 등분한 중앙부를 정하고 $0.1 \mathrm{cc}$ 를 피내에 주입하여 $8 \sim 9 \mathrm{~mm}$ 의 창백한 융기가 생긴 것 을 표준으로 하였다. 판독은 48시간 후에 발적대 경결의 크기 수포 유무 괴사 유무등으로 나누었고 판정은 경결의 크기 0 5mm (횡경)까지 음성이고 $6 \mathrm{~mm}$ 이상을 양성 으로 정하였다. 과거의 B.C.G. 접종자의 결핵감염을 관 찰하기 위해 B.C.G. 접종 받은 유무 접종기간등을 조 사하였다.

\section{조 사 졀 과}

\section{1) 인구구성}

가) 성별 연령별 인구 구성

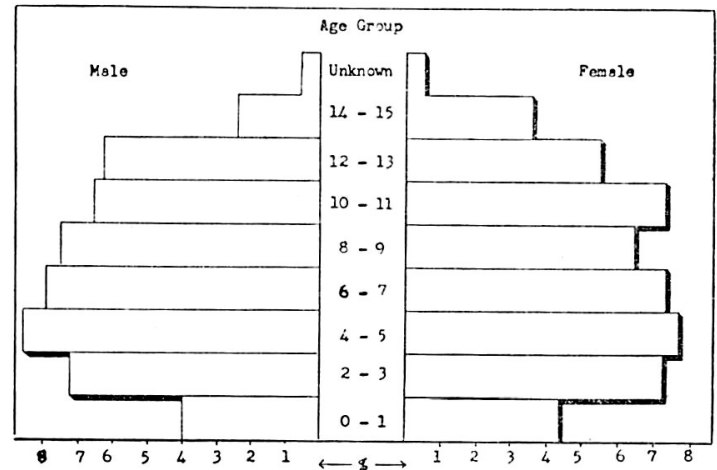

Fig. 1. Frequency distribution according to age groups and sex

Table 1. Population structure below 15 years of age

\begin{tabular}{|c|c|c|c|c|c|c|c|c|c|c|}
\hline age & $\begin{array}{l}\text { all } \\
\text { ages }\end{array}$ & & & & & & & $12 \widetilde{13}$ & & $\begin{array}{l}\text { un- } \\
\text { kno- } \\
\text { wn } \\
\end{array}$ \\
\hline Total & 1338 & 125 & 191 & 203 & 195 & 191 & 186 & 158 & 82 & 7 \\
\hline$\%$ & $(100.0)$ & 8.5 & 14.6 & 15 & 5.0 & 14.2 & 13.8 & 11.7 & 6.1 & 0.5 \\
\hline Male & 692 & 59 & 96 & 108 & 105 & 104 & 91 & 88 & 36 & 5 \\
\hline$\%$ & $(51.8)$ & 4.1 & 7.5 & 8.4 & 7.9 & 7.8 & 6.7 & 6.5 & 2.6 & 0.3 \\
\hline Female & 646 & 66 & 95 & 95 & 90 & 87 & 95 & 70 & 46 & 2 \\
\hline$\%$ & $(48.2)$ & 4.4 & 7.1 & 7.2 & 7.1 & 6.4 & 7.1 & 5.2 & 3.5 & 0.2 \\
\hline
\end{tabular}

15세미만의 인구구성은 (Table 1)에서 보는바와 같이 총인구 1,338 명으로 남자가 692 명 여자가 646 명으로 각 각 $51.8 \% 48.2 \%$ 을 차지하여 남자의 인구가 약간 많은 것을 볼수 있다. 연령별로 관찰하면 양성에 있어서 4 5 세가 $15.6 \%$ 로 가장 많고 $6 \sim 7$ 세가 $15.0 \% \quad 2 \sim 3$ 세가 $14.6 \%$ 의 순위로 많은 것을 볼수 있다. $0 \sim 5$ 세까지의 미 취학 아동이 $38.7 \%$ 6 15세역령이 $61.3 \%$ 을 차지하며 미상연령이 $0.5 \%$ 를 차지하고 있다 남녀에 있어서는 4 5 세의 연령이 각각 남자가 $8.4 \%$ 여자가 $7.2 \%$ 로서 가 장 많음을 볼수 있으며 남자에서는 6 7세가 7.9\% 8 9 세에서 $7.8 \%$ 이며 여자에서는 $6 \sim 7$ 세, $2 \sim 3$ 세에서 같은 $7.1 \%$ 로서 남녀 비슷한 순위를 보여주고 있다. $0 \sim 5$ 세인 미취학 아동에서는 남자가 전체의 $51.8 \%$ 중 $20.0 \%$ 여자 에서는 전체 $48.2 \%$ 중 $0 \sim 5$ 세가 $18.7 \%$ 로 비슷한 수치 
이고 $6 \sim 15$ 세에서도 남녀 각각 $31.8 \%$ 및 $29.5 \%$ 을 차지 하고 있다.

\section{2) 수검상황}

\section{가) 총수검율}

전체인구 1,338 명중 tuberculin 액 주사에 응한자가 1,163 명으로 $86.9 \%$ 을 차지하고 반응을 판독함으로서 검 사를 완료한 수가 1,140 명으로 충인구 1,338 명에 해 당해 서 완전 수검율이 $85.2 \%$ 을 보여주고 있다.

\section{나) 성별 수검율}

성별에 있어서는 table 2 와 같이 남자 인구 692 명중 tuberculin 액 주사에 읂한자 수가 602 명으로 $86.9 \%$ 이고 반웅검사 완료자수가 585 명으로 총인구 692 명에 해당해 서 완전 수검율이 $84.5 \%$ 이다.

Table 2. Coverage of tuberculin test(testing and reading) according to sex

\begin{tabular}{l|r|r|r|r|r}
\hline \hline & $\begin{array}{l}\text { Total } \\
\text { No. }\end{array}$ & $\begin{array}{c}\text { No. } \\
\text { tested }\end{array}$ & \multicolumn{1}{|c|}{$\begin{array}{l}\text { No. } \\
\text { read }\end{array}$} & $\begin{array}{l}\text { \% of } \\
\text { tested }\end{array}$ & $\begin{array}{l}\% \text { of } \\
\text { complete } \\
\text { Tested }\end{array}$ \\
\hline Total & 1,338 & 1,163 & 1,140 & 86.9 & 85.2 \\
Male & 692 & 602 & 585 & 86.9 & 84.5 \\
Female & 646 & 561 & 555 & 86.8 & 85.9 \\
\hline
\end{tabular}

여자에서는 총인구 646 명중 tuberculin 액 주사에 응 한자 수가 561 녕으로 $86.8 \%$ 이고 반응검사 완료자 수가 555 명으로 $85.9 \%$ 을 차지하여 남자보다 약간 높은 율을 보여주고 있다.

\section{다) 연령별 수검율}

연령별에 있어서 Table 3 과 같이 0 1세에서 완전 수 검율이 $92.8 \%$ 로 가장 높은율을 나타내었고 $6 \sim 7$ 세에서 $90.7 \%$ 8 9세에서 $90.0 \%$ 4 5세에서 $89.6 \%$ 의 순위를 차지하고 연령이 높을수록 적은율을 차지하여 14 15세 에서 $64.6 \%$ 로 가장 적은 율을 나타내고 있다.

\section{3) Tuberculin반응 양성율}

\section{가) 총양성율}

Table 4 와 같이 총검사 완료자수 1,140 명중 180 명이 양성으로 나타내어 $15.8 \%$ 을 보여주고 있다.

\section{나) 성별 Tuberculin 반응양성율}

Table 4와 같이 남자에서는 총검사 완료자수 585 명중 97 명이 양성으로 $16.5 \%$ 을 차지하고 여자 총검사 완료자 수 555 명중 83 명이 양성으로 $14.9 \%$ 을 나타내어 남자가 약간 높은 율을 보여주고 있다.

다) 연령별 양성율

연령별양성율은 Table 4 와 같이 $14 \sim 15$ 세에서 $33.9 \%$ 로 가장 높은율을 보이고 연령이 낮을수록 양성율이 낮

Table 3. Coverage of tubercuilin test (testing, reading) according to age groups

\begin{tabular}{l|r|r|r|r|r|r|r|r|r|r}
\hline \hline & allages & $0 \sim 1$ & $2 \sim 3$ & $4 \sim 5$ & $6 \sim 7$ & $8 \sim 9$ & $10 \sim 11$ & $12 \sim 13$ & $14 \sim 15$ & un-know \\
\hline Total No & 1,338 & 125 & 191 & 203 & 195 & 191 & 186 & 158 & 82 & 7 \\
No, tested & 1,163 & 117 & 170 & 188 & 178 & 175 & 163 & 117 & 54 & 1 \\
No, read & 1,140 & 116 & 165 & 182 & 177 & 172 & 161 & 113 & 53 & 1 \\
$\%$ of tested & 86.9 & 93.6 & 89.1 & 92.6 & 91.2 & 91.6 & 87.6 & 74.1 & 65.8 & 14.2 \\
$\%$ of C. tested & 85.2 & 92.8 & 86.3 & 89.6 & 90.7 & 90.0 & 86.5 & 71.5 & 64.6 & 14.2 \\
\hline
\end{tabular}

Table 4.

Percentage of tuberculin positive reactors according to sex and age groups

\begin{tabular}{|c|c|c|c|c|c|c|c|c|c|c|}
\hline \multirow{2}{*}{ Age } & \multirow[t]{2}{*}{ Sex } & \multicolumn{3}{|c|}{ Total } & \multicolumn{3}{|c|}{ Male } & \multicolumn{3}{|c|}{ Female } \\
\hline & & No. read & + & $\%$ & No. read & + & $\%$ & No. read & + & $\%$ \\
\hline & all ages & 1,140 & 180 & 15.8 & 585 & 97 & 16.5 & 555 & 83 & 14.9 \\
\hline & $0 \sim 1$ & 116 & 0 & 0 & 56 & 0 & 0 & 60 & 0 & 0 \\
\hline & $2 \sim 3$ & 165 & 10 & 6.1 & 82 & 6 & 7.3 & 83 & 4 & 4.8 \\
\hline & $4 \sim 5$ & 182 & 16 & 8.7 & 92 & 7 & 7.6 & 90 & 9 & 10 \\
\hline & $6 \sim 7$ & 177 & 21 & 11.8 . & 97 & 13 & 13.4 & 80 & 8 & 10 \\
\hline & $8 \sim 9$ & 172 & 36 & 20.9 & 92 & 21 & 22.8 & 80 & 15 & 18.7 \\
\hline & $10 \sim 11$ & 161 & 42 & 26.1 & 79 & 21 & 26.5 & 82 & 21 & 25.5 \\
\hline & $12 \sim 13$ & 113 & 37 & 32.9 & 60 & 19 & 31.6 & 53 & 18 & 33.9 \\
\hline & $14 \sim 15$ & 53 & 18 & 33.9 & 27 & 10 & 37.0 & 26 & 8 & 30.7 \\
\hline & unknown & 1 & 0 & 0 & 0 & 0 & 0 & 2 & 0 & 0 \\
\hline
\end{tabular}


아지는 것을 관찰할 수 있다. (Fig. 2 참조) 0 1세에서 는 양성율이 $0 \%$ 이며 $2 \sim 3$ 세가 $6.1 \% \quad 4 \sim 5$ 세가 $8.7 \%$ 로 낮으며 $0 \sim 5$ 세의 미취학 아동에서는 총인구 463 명중 양 성자 26 명으로 $3.4 \%$ 를 나타내고 있다.

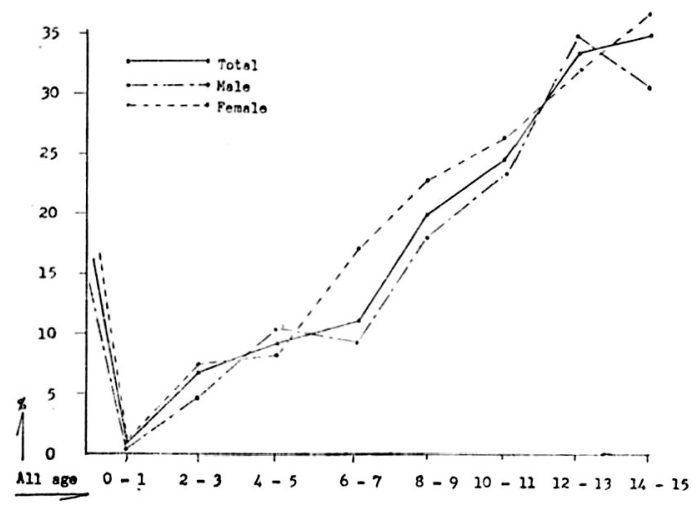

Fig. 2. Frequency distribution of tuberculin positive reactors by age and sex

\section{4) Tuberculin반응 경결의 크기 분포}

가) 성별 Tuberculin 반웅 경결의 크기 분포

Table 5에서 보는바와 같이 양성에 있어서 1,140명중 960 명이 경결의 크기 $0 \sim 5 \mathrm{~mm}$ 에 속함으로서 $84.2 \%$ 로 대부분을 차지하고 있다. $11 \sim 15 \mathrm{~mm}$ 의 크기에서 $6.5 \%$ $16 \sim 20 \mathrm{~mm}$ 에서 $4.2 \%$ 의 순위를 차지하고 있다. (Fig. 3 참조) 남자에서는 $0 \sim 5 \mathrm{~mm}$ 가 $83.4 \% \quad 11 \sim 15 \mathrm{~mm}$ 에서 $6.8 \% 16 \sim 20 \mathrm{~mm} 4.3 \%$ 의 순위이고 여자에 서는 $0 \sim 5 \mathrm{~mm}$ 가 $85.1 \% 11 \sim 15 \mathrm{~mm}$ 에서 $6.3 \% 16-20 \mathrm{~mm} 4.1 \%$ 로 남 녀같은 순위로 경결의 크기가 분포되어 있음을 볼수 있다.

나) 연령별 Tuberculin 반응경결의 크기분포

Table 6에서 보는 바와 같이 $0 \sim 5$ 세의 인구 463 명 중 437 명이 $0 \sim 5 \mathrm{~mm}$ 의 크기에 속함으로서 $94.4 \%$ 로 대부 분을 차지하고 $11 \sim 15 \mathrm{~mm}$ 에서 $1.9 \% \quad 16 \sim 20 \mathrm{~mm} \quad 1.7 \%$ 을 차지하고 있다. $6 \sim 15$ 세에서 총인구 677 명중 523 명이 $0 \sim 5 \mathrm{~mm}$ 로 $77.0 \%$ 이며 $11 \sim 15 \mathrm{~mm}$ 가 $9.8 \% 16 \sim 20 \mathrm{~mm}$ 가 $6.0 \%$ 로 같은 순위로 경결의 크기가 분포되어 있음을
결핵 및 호홉기질환 Vol. 16, No. 4, October, 1969

Table. 6. Relatine freguency distribution of tuberculin reactions according to induration size in $\mathrm{mm}$ among examinees by age

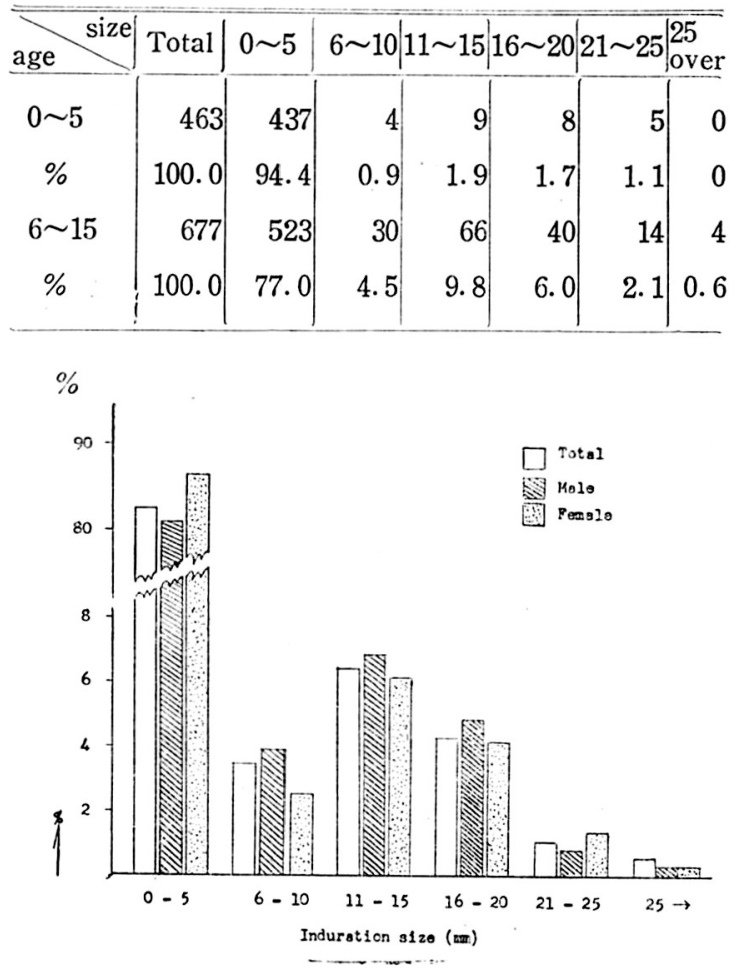

Fig. 3. Frequency distribution of tuberculin reactions according to induration $\operatorname{size}(\mathrm{mm})$ by sex.

볼수 있다. (Fig. 4 참조).

5) B. C. G. 기접종율

\section{가) 성별연령별 과거의 접종율}

과거 B.C.G. 접종자수는 Table 7에서와 같이 홍인구 1,163 명중 232 명이 접종하여 $19.8 \%$ 을 차지 하고 있다. 성 별에서는 남자가 $19.9 \%$ 여자가 $18.0 \%$ 로 남자가 약간 높은 율을 보여주고 있다. 연령별에서는 $10 \sim 11$ 세에서 $30.2 \%$ 로 가장접 종율이 높고 다음이 8 9세에서 $21.6 \%$ $12 \sim 13$ 세에서 $21.1 \%$ 의 순위로 접종율이 높고 $0 \sim 1$ 세

Table 5. Relative Frequency distribution of tuberculin reactions according to induation size in $\mathrm{mm}$ among examininees by sex

\begin{tabular}{|c|c|c|c|c|c|c|c|c|c|c|c|c|c|}
\hline & \multirow{2}{*}{$\frac{\text { Total }}{\text { No. }}$} & \multicolumn{2}{|c|}{$0 \sim 5$} & \multicolumn{2}{|c|}{$6 \sim 10$} & \multicolumn{2}{|c|}{$11 \sim 15$} & \multicolumn{2}{|c|}{$16 \sim 20$} & \multicolumn{2}{|c|}{$21 \sim 25$} & \multicolumn{2}{|c|}{25 over } \\
\hline & & No. & $\%$ & No. & $\%$ & No. & $\%$ & No. & $\%$ & No. & $\%$ & No. & $\%$ \\
\hline Total & 1,140 & 960 & 84.2 & 34 & 3.0 & 75 & 6.5 & 48 & 4.2 & 19 & 1.7 & 4 & 0.4 \\
\hline Male & 585 & 488 & 83.4 & 22 & 3.8 & 40 & 6.8 & 25 & 4.3 & 8 & 1.4 & 2 & 0.3 \\
\hline Female & 555 & 472 & 85.1 & 12 & 2.2 & 35 & 6.3 & 23 & 4.1 & 11 & 2.0 & 2 & 0.3 \\
\hline
\end{tabular}


결핵 및 호홉기질환 Vol. 6, No. 4, October, 1969

Table 7.

Percentage of B.C.G. vaccination according to sex age.

\begin{tabular}{|c|c|c|c|c|c|c|c|c|c|c|c|c|c|c|c|c|c|c|c|}
\hline \multirow{2}{*}{ Sex } & \multirow{2}{*}{$\begin{array}{l}\text { No. } \\
\text { tested }\end{array}$} & \multirow{2}{*}{$\begin{array}{l}\text { No. } \\
\text { B.C.G. } \\
\text { vacci. }\end{array}$} & \multirow{2}{*}{$\%$} & \multicolumn{2}{|c|}{$0 \sim 1$} & \multicolumn{2}{|c|}{$2 \sim 3$} & \multicolumn{2}{|c|}{$4 \sim 5$} & \multicolumn{2}{|c|}{$6 \sim 7$} & \multicolumn{2}{|c|}{$8 \sim 9$} & \multicolumn{2}{|c|}{$10 \sim 11$} & \multicolumn{2}{|c|}{$12 \sim 13$} & \multicolumn{2}{|c|}{$14 \sim 15$} \\
\hline & & & & No & $\%$ & No & $\%$ & No & $\%$ & 1 & $\%$ & No & $\%$ & No & $\%$ & No & $\%$ & No & $\%$ \\
\hline tal & 1,163 & 232 & 19.8 & 2 & 0.8 & 8 & 3.4 & 5 & $z$ & 22 & & 00 & & 70 & & & & & \\
\hline ale & 602 & 128 & 19.9 & 0 & 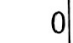 & 8 & 6.2 & 2 & 1.6 & 13 & 10.1 & 25 & 19.5 & 36 & 28.2 & & 24.3 & & 10.1 \\
\hline emale & 561 & 104 & 18.0 & 2 & 19 & 0 & 0 & 3 & 2.9 & a & 8.7 & 25 & 24.0 & 34 & 32.7 & & 17.3 & & 12.5 \\
\hline
\end{tabular}

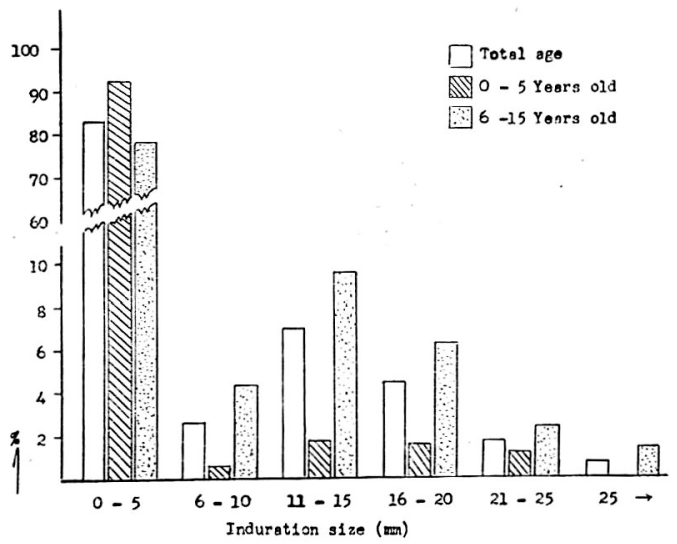

Fig. 4. Frequency distribution of induration size according to all ages, $0 \sim 5$ year old $6 \sim 15$ yearsold.

$0.8 \%$ 로 가장 접종율이 낮은 것을 볼수 있다.

6) B. C. G. 접종 반흔 유무별 Tuberculin반응 양성율

가) B.C.G. 접종 무반흔자에서의 양성율

B.C.G. 접종 무반흔자에서 양성율은 Table 8에서와 같 이 무반흔자 총인구 919 명중 148 명이 양성으로서 $16.1 \%$ 를 차지하고 있다. 성별에서는 남자가 $17.6 \%$ 여자가 $12.3 \%$ 로 남자가 높고 연령별에서는 $12 \sim 13$ 세에서 50.7

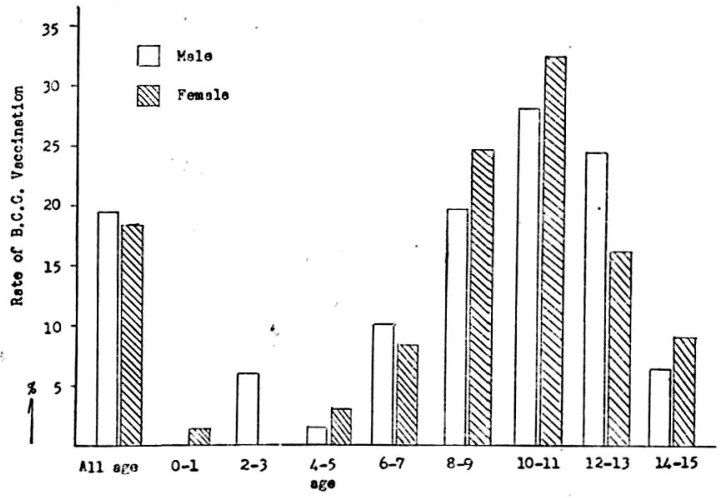

Fig. 5. Percentage of B. C.G. vaccination according to sex and age.
$\%$ 로 가장 높고 다음이 $14 \sim 15$ 세에서 $35.7 \% 10 \sim 11$ 세에 서 $35.4 \%$ 8 9세에서 $21.7 \%$ 로 연령이 높을수록 양전 율이 높은 것을 알수 있다.

나) B.C.G. 접종 유반흔자에서의 양성율

B.C. G. 접종 유반흔자에서는 Table 9 과 같이 유반흔자 총인구 221 명중 32 명이 양성으로 $14.4 \%$ 를 차지하고 있 다. 성별에서는 남자가 $12.5 \%$ 여자가 $16.8 \%$ 로 여자가 높고 연 령별에서는 $14 \sim 15$ 세에서 $32.0 \%$ 로 가장 높고 다 음이 4 5세에서 $20.0 \%$ 8 9세에서 $18.7 \% \quad 10 \sim 11$ 세에 서 $13.2 \%$ 의 순위를 차지하고 있다.

Table 8. Rate of positive reactors among examinees with out old B.C.G. scar

\begin{tabular}{|c|c|c|c|c|c|c|}
\hline age & No. read & $\mid \begin{array}{c}\text { No. } \\
\text { with out } \\
\text { old scar }\end{array}$ & $\begin{array}{c}\text { No. } \\
\text { positive }\end{array}$ & $\begin{array}{c}\% \\
\text { Total }\end{array}$ & $\begin{array}{c}\% \\
\text { Male }\end{array}$ & Female \\
\hline allages & 1,140 & 919 & 148 & 16.1 & 17.6 & 12.3 \\
\hline $0 \sim 1$ & 116 & 114 & 0 & 0 & 0 & 0 \\
\hline $2 \sim 3$ & 165 & 160 & 10 & 6.2 & 7.7 & 4.8 \\
\hline $4 \sim 5$ & 182 & 177 & 15 & 8.4 & 7.7 & 9.1 \\
\hline $6 \sim 7$ & 177 & 155 & 19 & 12.2 & 15.4 & 8.4 \\
\hline $8 \sim 9$ & 172 & 124 & 27 & 21.7 & 23. 1 & 20.0 \\
\hline $10 \sim 11$ & 161 & 93 & 33 & 35.4 & 39.5 & 32.0 \\
\hline $12 \sim 13$ & 113 & 67 & 34 & 50.7 & 53.1 & 48.5 \\
\hline $14 \sim 15$ & 53 & 28 & 10 & 35. & 8 & 28.5 \\
\hline $\begin{array}{c}\text { unkn- } \\
\text { own }\end{array}$ & 1 & 1 & 0 & & & 0 \\
\hline
\end{tabular}

본조사 지역의 인구 구성은 남녀에 있어 4 5세가 15.6 $\%$ 로 가장 많고 미취학아동 0 5세가 $38.7 \%$ 6 15세의 취학아동이 $61.3 \%$ 이며 $14 \sim 15$ 세아동이 $6.1 \%$ 로 가장 적 고 다음이 $0 \sim 1$ 세가 $8.5 \%$ 로 적은율을 차지하고 있다.

수검성적은 완전수검율이 $85.2 \%$ 로 남녀의 차이는 크 지 않음을 볼수 있다. 
Table 9. Rate of positive seactors among exominees with old B. C.G. scar

\begin{tabular}{r|r|r|r|r|r|r}
\hline Age & $\begin{array}{c}\text { No. } \\
\text { read }\end{array}$ & $\begin{array}{c}\text { No. } \\
\text { with } \\
\text { old scar }\end{array}$ & $\begin{array}{c}\text { No. } \\
\text { Positive }\end{array}$ & $\begin{array}{c}\% \\
\text { Total }\end{array}$ & $\begin{array}{c}\% \text { Male } \\
\text { Memale }\end{array}$ \\
\hline allages & 1,140 & 221 & 32 & 14.4 & 12.5 & 16.5 \\
$0 \sim 1$ & 116 & 2 & 0 & 0 & 0 & 0 \\
$2 \sim 3$ & 165 & 5 & 0 & 0 & 0 & 0 \\
$4 \sim 5$ & 182 & 5 & 1 & 20.0 & 0 & 33.3 \\
$6 \sim 7$ & 177 & 22 & 2 & 9.1 & 0 & 22.2 \\
$8 \sim 9$ & 172 & 48 & 9 & 18.7 & 21.7 & 16.0 \\
$10 \sim 11$ & 161 & 68 & 9 & 13.2 & 11.1 & 15.6 \\
$12 \sim 13$ & 113 & 46 & 3 & 6.5 & 7.1 & 5.5 \\
$14 \sim 15$ & 53 & 25 & 8 & 32.0 & 30.7 & 33.3 \\
unkn- & 1 & 0 & 0 & 0 & 0 & 0 \\
own & & & & & \\
\hline
\end{tabular}

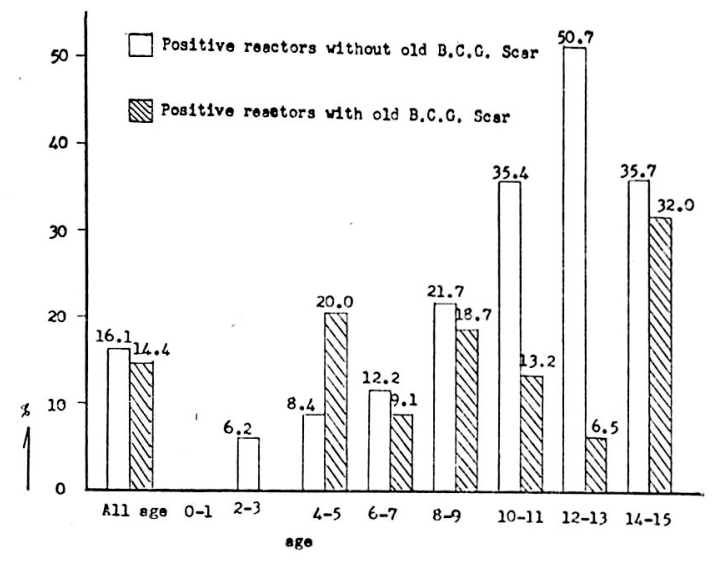

Fig. 6. Correlation between positive tubercalin reaction and B.C.G. vaccination

1965년 전국 결핵실태 조사에서1) tuberculin 완전수검 · 율은 $95.2 \%$ 로 이에 비하면 적은 율을 나타내며 1963년 서울시 인현동민 ${ }^{2}$ 에 대한 집 단수검율은 $78.6 \%$ 로 이에 비하면 높은 율을 보여주고 있다.

연령별 수검성젹은 연령이 증가할수록 수검율이 저하 되여 $0 \sim 1$ 세에서 $92.8 \%$ 로 가장 높고 $14 \sim 15$ 세 즉 중학 진학 연령에서 $64.6 \%$ 로 가장 저율인 것을 볼수 있다.

이겻은 농촌의 특색으로 학령기의 도시 유출관계와 밀 접한 관계가 있는 것으로 생각된다.

Tuberculin반응 양성율은 남녀 총연령에서 $15.8 \%$ 을 나타내고 남자에서 $16.5 \%$ 로 여자 $14.9 \%$ 보다 약간 높은
결핵 및 호홉기질환 Vol. 16, No. 4, October, 1969

율을 보여주고 있다. 연령별에서는 0 1세에서는 양성자 가 없고 $14 \sim 15$ 세에서 $33.9 \%$ 로 가장 많고 연령이 증가할 수록 양성율이 높아져 이것은 감염 될 기회가 많고 또는 B. C. G접종 기회로 인하여 당연한 것으로 불수 있다.

6 세미만 미취학아동에서는 본 조사지역이 $5.6 \%$ 로 나 타내는데 비해 전국 결핵실태 ${ }^{1)}$ 조사에서 본 미취학아동 B. C. G. 접종자 가운데 양성율이 $44 \%$ 미접종자가 $16.8 \%$ 로 훨씬 저율을 나타내며 서울시 인현동민 ${ }^{2)} 0$ 4세의 양 성율은 남녀각각 19\% 18\% 보다 저율이며 1964년 전주 시 ${ }^{3)}$ 학령기 아동 $6 \sim 13$ 세에서 $25.3 \%$ 의 양성율에 비해 본 조사지역의 $6 \sim 13$ 세에서 는 $21.8 \%$ 로 도시보다는 농촌 아동에 있어 결핵감염이 적은 것을 관찰할 수 있다.

Tuberculin반응 경결의 크기 분포는 남녀에 있어서 또 는 연령 0 5세및 6 15세별로 음성을 제외한 양성자중 경결의 크기분포는 $11 \sim 15 \mathrm{~mm}$ 에서 $16 \sim 20 \mathrm{~mm}$ 가 가장 많 이 차지하고 있음을 볼수 있다. 이것은 또한 전국 결핵실 태조사에서 나타난 성별 연령별에서 $18 \sim 20 \mathrm{~mm}$ 에서 가 장 높은 율을 차지하고 서울시 인현동 동민 결핵 감염조 사에서도 $16 \mathrm{~mm}$ 를 전후로 가장 고율을 나타내고 있음은 다같은 현상이라고 볼수 있다.

B.C.G. 총접종율은 $19.8 \%$ 로 남자 $19.9 \%$ 가 여자 $18.0 \%$ 보다 약간 높은 것을 알수 있다. 연령별에서는 조 사 당시 10 11세아동에서 $30.2 \%$ 로 가장 많고 연령이 증 가할수록 접종율이 높은 것은 당연한 것으로 생각된다.

전국 결핵실태조사에 의하면 군부 B.C.G. 접종율이 $14.4 \%$ 시부가 $21.2 \%$ 로 도시보다는 농촌이 접종율이 적으며 또한 이것은 전연령 층임으로 본 조사지역과 비교 할수 없는 것으로 생각된다.

B. C. G. 접종 반흔유무별 tuberculin 양성을 비교 관찰 하면 유반혼자에 있어 총양성율이 $14.4 \%$ 에 비해 무반 혼자는 $16.1 \%$ 로 B.C.G. 접종을 받은 일이 없는 사람에 있어서 양성율이 높은 것을 관찰할수 있다. 성별에서는 무 반혼자에서의 남자가 $17.6 \%$ 로 여자 $12.3 \%$ 보다 높은반 면 유반흔자에서는 여자가 $16.8 \%$ 로 남자 $12.5 \%$ 보다 높 다.

연령별에서는 무반훈자에서 12 13세에서 $53.1 \%$ 로 가장 높고 유반혼자에세 $14 \sim 15$ 세에서 $30.7 \%$ 로 가장 높 으며 무반혼자에서는 연령이 높을수록 양성율이 높아지 는 경향으로 자연감염이 증가되었다고 볼수있는데 유반 흔자에서는 불규칙하게 연령증가와 관계없는 양성율을 관찰할 수 있다. 무반혼자 자연감염에서는 0 5세까지 자 연감염 양성율이 $5.5 \%$ 인데 비해 유반흔자는 $8.3 \%$ 로서 양성율이 높으며 반대로 6 15세에서는 무반혼자 $26.3 \%$ 에 비해 유반혼자 $14.8 \%$ 도 연령이 많은 층에서는 오히려 
무반혼자가 양성율이 높은 것을 관찰할 수 있다.

이것은 전국 결핵실태조사에서 나타난 $0 \sim 4$ 세의 B.C. . G. 기 접종자의 양성율이 $32.9 \%$ 이고 미 접종자 $12 \%$ 이며 6 세미만의 미취학아동에서 접종자의 양전율이 $44 \%$ 미접 종자가 $16.8 \%$ 로서 접종자의 양성율이 높은 반먼에 14 15 세및 15 세이상에서는 반대로 미접종자의 양성율이 높 은 것은 본조사지역과 같은 현상이라고 볼수 있다.

이것은 연령이 많은 층에서는 과거에 B.C.G. 접종을 받았음에도 이미 반응이 음전한 까닦이 아닌가 생각된다.

\section{결 론}

1969년 1월 12일부터 18일까지 경기도 양주군 수동면 북부 7 개리 주민 만 15 세미만의 남녀아동에게 tuberculin검사를 실시하여 다음과 같은 결론을 얻었다.

1) 완전수검율은 총연령에 있어서 $85.2 \%$ 남녀의 차 이는 별로 없고 연령이 증가할 수록 수검율이 저하되었다.

2) Tuberculin 총양성율은 $15.8 \%$ 이고 남자 $16.5 \%$ 는 여 자 $14.9 \%$ 보다 약간 높고 연령이 높을수록 증가하는 경 향이 있어 $0 \sim 1$ 세에서는 $0 \%$ 이고 $14 \sim 15$ 세에서 $33.9 \%$ 로 가장 높았다.

3) Tuberculin 반응 경결의 크기 분포는 음성을 제외하 고 양성 $15.8 \%$ 중 $11 \sim 15 \mathrm{~mm}$ 에서 남자가 $6.8 \%$ 여자가 $6.3 \%$ 도 가장 많이 차지하고 연령별에서는 $11 \sim 15 \mathrm{~mm}$ 가 $0 \sim 5$ 세에서 $1.9 \% 6 \sim 15$ 세에서 $9.8 \%$ 로 가장 많이 차 지하고 있음을 관찰할수 있었다.

4) B.C.G. 총접종율은 $19.8 \%$ 도 남자가 $19.9 \%$ 여자 가 $18.0 \%$ 로 남자가 약간 높으며 연령이 증가할수록 접 종율이 높은 것을 관찰할 수 있다.

5) B.C.G. 접종 반흔 유무별 tuberculin 반응검사는 총양성율이 무반흔자 $16.1 \%$ 가 유반흔자 $14.4 \%$ 보다 약 간 높았다. 연령별로는 0 5세에서는 무반흔자가 $5.5 \%$ 로 유반흔자 $8.3 \%$ 보다 저율인 반면 $6 \sim 15$ 세에서는 무반 흔자 $26.3 \%$ 가 유반흔자 $14.8 \%$ 보다 고율로 연령이 높 은층에서는 B.C.G. 접종을 받았음에도 양성율이 낮은 것을 관찰할 수 있었다.

\section{참 고 문 헌}

1. 대한민국결핵실태조사결과 보건사회부 대한결핵협 회. 1965 .

2. 대한결 핵학회. 대한결핵헙회 결핵 및 호흡기질환 시 범지인 중구인현동 동민에 있어서의 결핵감염율 $\mathrm{Vol}$ $16,1963$.

3. 대한결핵학회 대한결핵협회 결핵 및 호흡기질환 $T u$ berculin allergy 발생에 미치는 국산 B.C.G.의 변 역효과 Vol. 18, 1964.

4. 대한결핵학회 대한결핵협희 결핵 및 호홉기질환 $T u$ berculin 반응도와 패결핵 유병율과의 상관에 대한 역학적 고찰

5. 이화여자대학교의학회. 의학회지 우리나라 일개 농 촌지역의 보건실태조사연구 1965.

6. 대한의학협회 대한의학회지 소아결핵의 원인 및 진 단과 치료 Vol. 5, No. 31962.

7. 대한결핵학희 대한결핵협희 결핵 및 호홉기질환 철 도청 집단검진 No. 211965.

8. 대한결핵학회 결핵과 호흡기질환 결 핵의 진단법 No. $13,1962$.

9. M. Dunlevy: Five year's experience of B.C.G. Vaccination in Dublin of Hyg. 1954. 29:1147.

10. Edward L. B. MognusK. : Certain characteristics of B.C.G. induced Tuberculin sensitivity, Bull WHO. 12:123-142 1955.

11. Phyllis Q. Edwards and Lydia B. Edward: Story of the Tuberculin test from epidemiologic View point, Am. Rev. Resp. Disease, No. 1, Jon. 1960.

12. William W. Johnston, Herbert A. Saltzman, J. Harned Bufkin: The tuberculin test and the diagnosis of clinical Tuberculosis, Am. Rev. Resp. Disease, No. 2, Feb. 1960.

13. Annual Report, tuberculosis control: Ministory of Health and Social Affairs, Republic of Korea, 1960. 